\title{
Weird Human Oocytes after Ovum Pickup in an ICSI Cycle
}

\author{
Ahmed Samy Saad*, Sahar Eissa and Waleed Abdellateef \\ Department of Obstetrics and Gynecology, Benha University \& Hawaa Fertility Center, Egypt
}

Submission: December 18, 2017; Published: January 05, 2018

*Corresponding author: Ahmed Samy Saad, Assistant professor of Obstetrics and Gynecology, Benha University \& Clinical director and general manager of Hawaa Fertility Center, Egypt, Email: drahmedsaad@live.com

\section{Case Report}

This is a short but an interesting case report case. A female patient 38 years old undergone an ICSI cycle in our fertility center (Hawaa Fertility Center) due to male factor as her husband was azoospermic which had a testicular biopsy 3 months before starting the ART cycle in which motile sperms were detected and frozen in liquid nitrogen. She was expected to be a low responder due to poor AFC and Low AMH level 0.6ng/ml. So the patient was given a short protocol in the form of Triptorelin acetate $0.05 \mathrm{ml} / \mathrm{d}$ and 300IU HMG daily for 9 days then was given 10.000IU HCG when 3 dominant follicles were $18 \mathrm{~mm}$ in diameter. She was scheduled for ovum pick up after $35 \mathrm{hrs}$. Before oocyte retrieval we had 3 follicles $>18 \mathrm{~mm}$ in diameter in the right ovary and 2 at the left ovary. Retrieval was done and after aspiration and searching on the stereomicroscopy we didn't find the usual cumulus-oocyte complexes but instead we find this weird rounded structure and so the ICSI cycle was cancelled because we didn't find any normal cumulus-oocyte complexes to begin with. This was the first time for us to see these findings and we will be happy if any embryologist has detected such images before and if she did have any treatment in such cases because when we tried another cycles 6 months later we had only 3 follicles by vaginal ultrasound but upon aspiration we didn't find any oocyte but all the follicles were empty (Figure 1).

Figure 1: Oocyte.

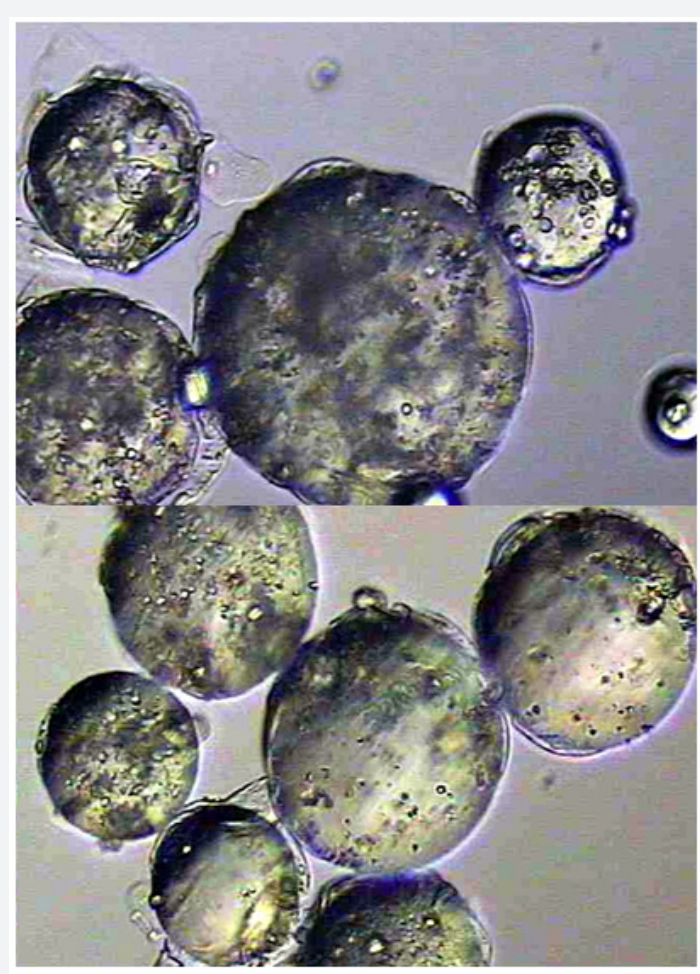


(C) This work is licensed under Creative (1) Commons Attribution 4.0 Licens DOI: 10.19080/JOJCS.2018.05.555667

\section{Your next submission with Juniper Publishers} will reach you the below assets

- Quality Editorial service

- Swift Peer Review

- Reprints availability

- E-prints Service

- Manuscript Podcast for convenient understanding

- Global attainment for your research

- Manuscript accessibility in different formats ( Pdf, E-pub, Full Text, Audio)

- Unceasing customer service

Track the below URL for one-step submission https://juniperpublishers.com/online-submission.php 